\title{
Acquisition of Entrepreneurial Skills by Polytechnic Students in Osun State, Nigeria
}

\author{
Tajudeen Adewumi Adebisi (PhD) \\ Department of Adult Education and Lifelong Learning, Faculty of Education, \\ Obafemi Awolowo University, Ile-Ife, Osun State, Nigeria \\ tadebisi@oauife.edu.ng; jonathanadebisi@yahoo.com
}

Doi:10.5901/jesr.2015.v5n1p83

\begin{abstract}
This paper assesses acquisition of entrepreneurial skills by polytechnic students in Osun State, Nigeria. It identifies courses through which entrepreneurial skills could be acquired; examines availability of training facilities; determines whether or not polytechnic students do the mandatory industrial training or students' industrial work experience scheme, and find out attitudes of students to entrepreneurial skills acquisition. Survey research design was used. The population comprised all the polytechnic students in Higher National Diploma (HND). The sample comprised 300 participants from purposefully selected three government-owned polytechnics. Descriptive and inferential statistics were used to analyze data gathered through structured questionnaire. The results showed that there were over 50 entrepreneurship-based courses offered in polytechnics in the State. Availability of relevant skills training facilities was lacking. Both the industrial training and students' industrial work experience scheme positively contributed to acquisition of skills. Students' attitudes towards entrepreneurial skills acquisition were poor. Relevant workable recommendations were suggested.
\end{abstract}

Keywords: polytechnic, acquisition, entrepreneurial skills, training facilities

\section{Introduction}

Several attempts have been made by successive government in Nigeria from time immemorial to empower the youth with employable skills with a view to alleviating unemployment and poverty. For instance the establishment of National Poverty Eradication Program (NAPEP) 2000/2001, Structural Adjustment Program (SAP) 1988/89, and National Directorate of Employment (NDE) 1986, among others are government efforts towards eradicating joblessness, unemployment and poverty among the people. However, all these programs and government interventions seem not to address the real foundational problem which is hidden in the Nigerian education system and its products. The Polytechnic education in Nigeria is established to impart the youths with practical and employable skills. Regrettably however, contrary seems to be the situation. Teaming number of polytechnic graduates are unemployed and jobless. This scenario is not far-fetched from the fact that they were ill-equipped with entrepreneurial skills in the course of their education. Thus there is need to assess acquisition of entrepreneurial skills by prospective students of polytechnics in the State of Osun, Nigeria with a view to finding out the strengths or weaknesses of polytechnic education in equipping the Nigerian youths with necessary and relevant employable skills. Hence, this study becomes very germane.

The polytechnic education in Nigeria as in other parts of the world is established with a view to imparting relevant and necessary work skills in prospective students. Every course of study in Nigeria polytechnics has potential for entrepreneurship. It is, however, regrettable that most Nigerian youths, who attend polytechnics, lack entrepreneurial skills which could make them to be employable or self-employed/self-reliant after their graduation from school. Kitzer (2007) defined entrepreneurship as a process in which individuals pursue opportunities, fulfilling needs and wants through innovations, together with the attendant risks. According to Klaipeda Business School (2009) Entrepreneurship is defined as the main skill necessary in order to conform to the conditions of the ever-changing knowledge and information society. Nwanaka and Amaechule (2011) are of the view that Nigeria's social and economic problems will be drastically reduced if students are given adequate vocational training in skills, raw materials, machineries and equipment. According to Maigida, Saba \& Namkere (2013), the modern world economy requires innovation, training, reinventing in vocational education and entrepreneurship training that will significantly favor the youth. World over, there is always job for the skilled. Dhenak (2010) laments that though there is abundant labor supply there is generally scarcity of skills at all levels of socio-economy. There is no doubt that joblessness and unemployment continue to grow unabated in Nigeria due to poor acquisition of entrepreneurial/vocational skills. According to Osemeke (2012), a skill implies an ability which can be developed, not necessarily inborn, and which is manifested in performance, not merely in potential. In Europe, according 
to Klaipeda Business School (2009), all participating institutions in entrepreneurship training have come to a common decision that the entrepreneurial skills the students are able to acquire during their regular study process are not enough for a common European (labor) market. Thus, it is imperative that polytechnic graduates must possess demonstrable work skills.

Nwanaka and Amaehule (2011) emphatically states that it is only with skilled men that materials can be harnessed, manipulated and transformed into products. Likewise, Maigida, Saba \& Namkere (2013) believe that entrepreneurship is the practice of consistently converting goods and ideas into productive and profitable commercial ventures. Entrepreneurship is an ability to think creatively and become an effective problem solver (Maigida, Saba \& Namkere, 2013). Comfort and Bonaventure (2012) consider entrepreneurial skills as business skills which one acquires to function effectively in the turbulent business environment as an independent or self-employed person in order to improve one's economic status and the society at large. Maigida, Saba \& Namkere (2013) explain that entrepreneurship is a special type of labor that requires the assembling of all factors of production: capital, land and labor and tries to ensure optimum utilization of them to ensure maximum profit. There are resources, materials and potentialities lying fallow unexplored; these are only waiting for the skilled, who will explore, harness, manipulate and transform them into saleable products.

According to Nwanaka and Amaechule (2011) there are three stages in skills acquisition: theoretical, practical and exposure to challenges. An important factor in skills acquisition process is exposure to practical situations where these skills are displayed and utilized. It is thus essential that polytechnic students be given the required practical skills, which they need to cope with emerging challenges of the modern world. In order to expose polytechnic students to real work situations, they are mandated to go for one year industrial training (IT) or students' industrial work experience scheme (SIWES) in job areas relevant to their courses of study after their first two years (Ordinary National Diploma - OND), before proceeding for their Higher National Diploma (HND). The following, according to Comfort and Bonaventure (2012), are the objectives of Students' Industrial Work Experience Scheme (SIWES):

i. To provide an avenue for students in institutions of higher learning to acquire industrial skills and experience in their courses of study.

ii. To prepare students for the industrial work situations they are to meet after graduating.

iii. To expose students to work methods and techniques in handling equipment and machinery that may not be available in their institutions.

iv. To make the transition from school to the world of work easier and enhance students contacts for later job placement.

v. To enlist and strengthen employers' involvement in the entire educational process and prepare students for employment in industry and commerce.

Regrettably, Comfort and Bonaventure (2012) found out that the objectives of SIWES were not realized due to lack of seriousness on the part of some students, deployment of some students to offices that have nothing to do with their areas of specialization as well as the insensitivity of their respective institutions in approving placement for students in offices not related to their field of study. These, according Comfort and Bonaventure (2012) adversely affected their level of exposure to practical experiences required for self-reliance, self-employment, and the general employability in public and private sectors of the economy. They believe that students need exposure to areas that will benefit them based on their areas of specialization.

Polytechnic students should be encouraged and made to do their SIWES in workplaces relevant to their courses of study to enable them gain productive and profitable entrepreneurial skills. Comfort and Bonaventure (2012) concluded that one of the major ways students can gain the right experiences is when they are posted to the right offices with the right equipment and facilities; monitored closely and supervised effectively by both the institutions and industries-based supervisors. The youths need exposure in practical entrepreneurial work experience in order to be proficient in their chosen career and be useful to themselves and the society. Entrepreneurship which is a planned effort undertaken by an individual or individuals, institutions or agencies to develop the required competencies in people can easily be addressed through exposure to vocational options. Abubakar (2010) exemplified educational institutions and workplace as different contexts in which learning experiences may occur. Oziengbe (2009) also identified technical colleges and trade centers as two places where teaching of skills takes place in formal sector. In these centers, individuals are provided with needed skills that will enable them become proficient in both the public workplace and private employment. The principal criterion of skillfulness must be effective action under varying conditions (Maigida, Saba \& Namkere, 2013).

Skills can be cultivated or developed (Osemeke, 2012). Therefore to develop entrepreneurial skills in polytechnic students they need to be attached to workplaces for practical orientations. Osemeke (2012) identified conceptual skills, 
human skills, and technical skills. Technical skills, according to him, imply an understanding of, and proficiency in, a specific kind of entrepreneurial activity, particularly one involving methods, processes, procedures, or techniques. Technical skills involve specialized knowledge, and technical ability within that specialty, and facility in the use of tools and techniques of specific discipline - Osemeke (2012). Polytechnic students must be trained in handling work tools for their self-reliance. Maigida, Saba \& Namkere (2013) view that entrepreneurship is a special type of labor that requires the assembling of all factors of production: capital, land and labor and tries to ensure optimum utilization of them to ensure maximum profit.

According to Adeyemo (2009), skill is thought of as a quality of performance which does not depend solely upon a person's fundamental, innate capacities but must be developed through training, practice and experience. Skills represent particular ways of using capacities in relation to environmental demands (Adeyemo, 2009). He further emphasizes that entrepreneurial skills are the basic skills necessary to enable one starts, develops, finances, and succeeds in one's enterprise. He, therefore, identifies the conditions which promote acquisition and the change that will occur when the skill is acquired as two fundamental issues that must be considered when new skill is to acquired. Adeyemo (2009) reiterates that a learner of a new skill does not jump into operation without first receiving the necessary verbal instruction. The instruction, perhaps given in bits, units, modules or stages, according to him, must be fused together to form a skillful/skilled performance. It is, however, pathetic that education being received by Nigerian polytechnic students today is nothing more than only verbal instructions without any practical orientations to actualize what is instructed. According to Gumbari (2009), there is no issue that should be addressed as a matter of urgent national importance than that of skills acquisition by the youth considering the failure of our basic education to yield the expected positive results with its attendant consequences such as armed robbery, militancy, kidnapping, abduction for ransom and a lot of others.

According to Araba (2013) entrepreneurship is important as a diffusion mechanism to transform scientific inventions into new product and service innovations. Consequently, Araba (2013) counsels that institutions of higher education should offer chance to develop knowledge intensive high-growth enterprises from all academic disciplines, not just technical ones. He believes that higher education institutions should create an environment that fosters entrepreneurial mind-sets, skills and behaviors across organizations. Lending credence to IT/SIWES, Araba (2013) emphasizes that it is important to involve stakeholders inside and outside of higher education institutions in entrepreneurial skill training. He therefore recommends that if the polytechnic graduates are to enter the business world and entrepreneurship it is necessary to involve business people and entrepreneurs in the academic education process.

In conclusion, importance of entrepreneurial skills acquisition in job/employment creation cannot be overemphasized. Gumbari (2009) says that if third World countries especially Nigeria must be economically self-reliant, they must necessarily diversify their economies and as well encourage the youth to embrace self-employment through appropriate favorable policy environment that would facilitate skills acquisition, entrepreneurship and self-reliance.

\subsection{Purpose of the Study}

The general purpose of this study is to assess acquisition of entrepreneurial skills by polytechnic students in the State of Osun, Nigeria. Specifically, the study sought to:

i. identify courses/programs from which entrepreneurial skills could be acquired by polytechnic students;

ii. examine availability of relevant teaching/training facilities with which entrepreneurial skill could be acquired by polytechnic students;

iii. determine whether or not polytechnic students do their industrial training (I.T) or Students' Industrial Work Experience Scheme (SIWES) programs in job areas related to their course of studies; and,

iv. find out attitudes of polytechnic students towards acquisition of entrepreneurial skills.

\subsection{Research Questions}

i. What are the courses/programs from which entrepreneurial skills could be acquired by polytechnic students?

ii. Are there relevant teaching/training facilities with which entrepreneurial skills could be acquired by polytechnic students?

iii. Do polytechnic students do their Industrial Training (I.T)/Students Industrial Work Experience Scheme (SIWES) programs in job areas related to their courses of studies?

iv. What are the attitudes of students of polytechnics towards acquisition of entrepreneurial skills? 


\subsection{Hypotheses}

i. There will be no significant relationship between the department of students and availability of teaching/training facilities with which entrepreneurial skills could be acquired by polytechnic students.

ii. There will be no significant difference between the sex of students of polytechnics and their attitude towards acquisition of entrepreneurial skills.

iii. There will be no significant difference between the year of program of student and whether they do their IT/SIWES in job areas related to their course of studies.

\section{Methodology}

A descriptive survey research design was adopted for the study. In a typical survey the researcher selects a sample of respondents and administers a standardized questionnaire to them. The survey design is appropriate for this study, since the study is not truly experimental. Descriptive survey can provide information on the attitudes or other characteristics of a particular group. It is good in collecting information, demonstrate relationships and describe the world as it exists.

The population for this study comprised all the Polytechnic students running their Higher National Diploma (HND) in the State of Osun, Nigeria. There are 5 (five) Polytechnics in the State of Osun 3(three) public owned and 2(two) private owned. These are: Federal Polytechnic Ede, Osun State Polytechnic Iree, Osun State College of Technology Esa-oke, Interlinks polytechnic Igbajo, and The Polytechnic lle-Ife. The sample for this study consisted of 300 Higher National Diploma [HND] Polytechnics students drawn from 3 [three] government-owned polytechnics, these are: Federal Polytechnics Ede, Osun State Polytechnics Iree, and Osun State College of Technology Esa-Oke. Purposive and stratified random sampling techniques were employed. The three 3 polytechnics were purposively selected due to the fact that they run many more courses/programs than the private-owned ones, and they have many more accredited courses by the National University Commission [NUC] Than the private-owned Polytechnics. One hundred students were randomly selected from each of the three 3 polytechnics. Each 100 was stratified into 20 students per course/programs at the HND level. The rationale for limiting the sample to HND students is due to the fact that they have had the opportunity to go for the mandatory Industrial Training (I.T) or Students Industrial Work Experience Scheme (SIWES).

The research instrument was a structured/open-ended questionnaire which was divided into two sections: Section A comprised socio-demographic data of the participants, Section B consisted of a 21-item which elicited relevant information from the participants based on the pre-set objective of the study. Participants' responses were based on a four-point rating scale: [1] Agree [2] Strongly Agree [3] Disagree [4] Strongly Disagree. Both the face and the content validity were done with a view to ensuring that items on the questionnaire measure what they are meant for. Data was analyzed using descriptive and inferential statistical method. The data collected were tabulated and grouped according to questions relating to the research questions to which answers are being sought.

\subsection{Data Analysis}

The data collected were analyzed using descriptive and inferential statistics involving frequency counts and percentages. Out of the 300 questionnaire administered, 250 were returned and analyzed. The analyses are presented in the following Tables:

\subsection{Data Analysis and Discussion of Results}

Table 1: Sex Distribution of the Respondents

\begin{tabular}{|c|c|c|c|c|c|}
\hline & & Frequency & Percent & Valid Percent & Cumulative Percent \\
\hline \multirow{3}{*}{ Valid } & Male & 117 & 46.8 & 46.8 & 46.8 \\
\hline & Female & 133 & 53.2 & 53.2 & 100.0 \\
\hline & Total & 250 & 100.0 & 100.0 & \\
\hline
\end{tabular}




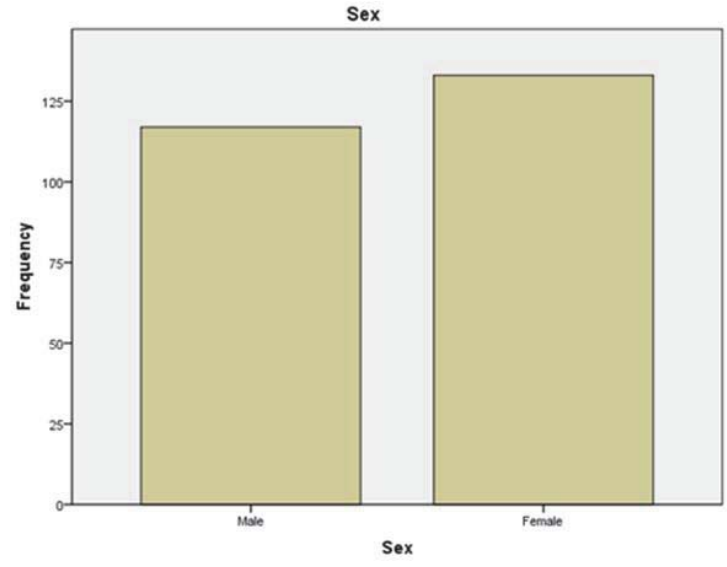

Figure 1: Sex Distribution of the Respondents

The analysis on Table 1 and as graphically depicted by Figure 1 shows that $117(46.8 \%)$ and 133 (53.2\%) of the participants were males and females respectively. This clearly shows the randomization as per the gender of the participants. Sample was not stratified by gender. However, female respondents are the majority.

Table 2: Distribution by Year of Program

\begin{tabular}{|cc|c|c|c|c|}
\hline & & Frequency & Percent & Valid Percent & Cumulative Percent \\
\hline \multirow{3}{*}{ Valid } & HND 1 & 108 & 43.2 & 43.2 & 43.2 \\
& HND 2 & 142 & 56.8 & 56.8 & 100.0 \\
& Total & 250 & 100.0 & 100.0 & \\
\hline
\end{tabular}

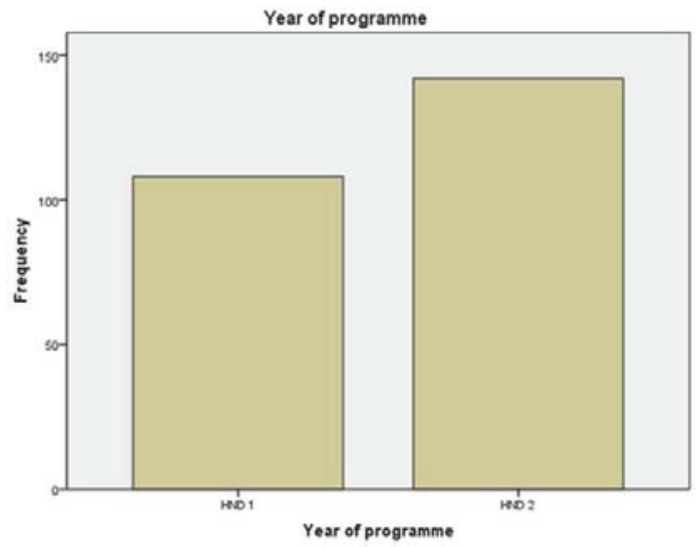

Figure 2: Distribution by Year of Program

Table 2 and Figure 2 show that 108 (43.2\%) respondents are in HND 1 while 142 (56.8\%) are in HND 2 of their program.

\subsubsection{Research question 1: What are the courses/programs from which entrepreneurial skills could be acquired by} polytechnic students?

As it earlier been said, all courses being offered in Nigerian polytechnics have entrepreneurial potential which prospective polytechnic students could explore. The available courses in Nigerian polytechnics as contained in the Joint Admissions and Matriculation Board (JAMB) brochure 2011 pages 459-504 are listed hereunder:

Agricultural engineering/technology, animal health and production technology, architectural technology, art and 
design, banking and finance, building technology, business administration and management, chemical engineering technology, civil engineering technology, computer science, cooperative economics and management, computer engineering, aircraft engineering technology, dental technology, dental therapy, electrical electronics engineering, estate management, fashion design and clothing technology, food technology, forestry technology, fisheries technology, foundry technology, hospitality management, glass/ceramics technology, geological technology, insurance, library and information science, social development, mass communication, mechanical engineering technology, mechatronics engineering technology, metallurgy, mineral resources engineering technology, nutrition and dietetics, printing technology, quantity surveying, polymer technology, science laboratory technology, leather technology, office technology and management, textiles technology, leisure and tourism management, urban and regional planning, wood and paper technology, music technology, surveying and geoinformatics, welding and fabrication technology, community health, health information management, environmental health, and pharmaceutical technology among others.

The polytechnic education in Nigeria has the responsibility of equipping prospective polytechnic students with relevant entrepreneurial skills from the above listed courses with a view to making them possess employable skills as well as self-reliant and self-employed potentials. It is, however, highly disappointing that majority of the polytechnic graduates are still in the job markets years after their graduation from school. The respondents' responses as per the departments and courses they offered in polytechnics are analyzed on Tables 3 and 4 as well as Figures 3 and 4.

Table 3: Distribution of Respondents by Department

\begin{tabular}{|l|c|c|c|c|}
\hline & Frequency & Percent & Valid Percent & Cumulative Percent \\
\hline Accountancy & 40 & 16.0 & 16.0 & 16.0 \\
Civil Eng. & 14 & 5.6 & 5.6 & 21.6 \\
Electrical/Electronic Eng & 50 & 20.0 & 20.0 & 41.6 \\
Environmental Studies & 2 & .8 & .8 & 42.4 \\
Hospitality \& Leisure Management & 120 & 48.0 & 48.0 & 90.4 \\
Valid Hospitality, Tourism and Leisure & 1 & .4 & .4 & 90.8 \\
Hospitality \& Leisure Management & 8 & 3.2 & 3.2 & 94.0 \\
Mechanical Engineering & 5 & 2.0 & 2.0 & 96.0 \\
Quantity Surveying & 8 & 3.2 & 3.2 & 99.2 \\
Statistics & 2 & .8 & .8 & 100.0 \\
Total & 250 & 100.0 & 100.0 & \\
\hline
\end{tabular}

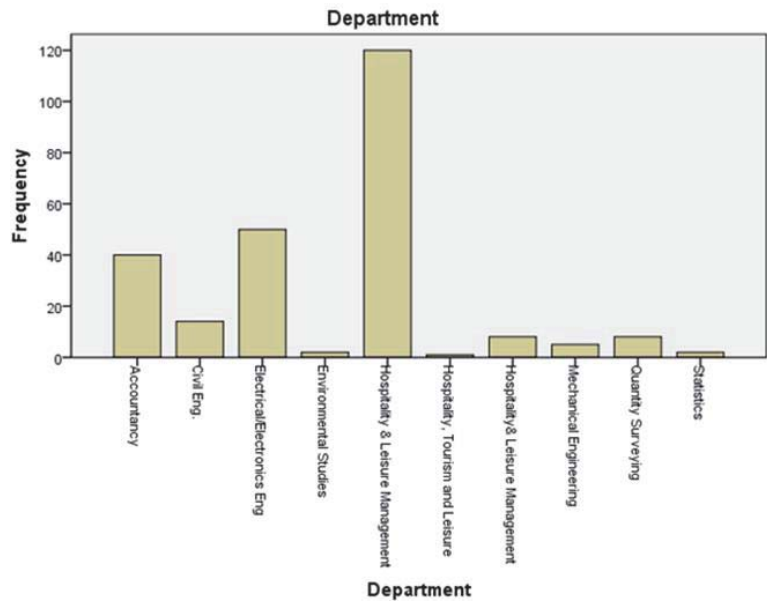

Figure 3: Distribution of Respondents by Department

According to Table 3 and shown by Figure 3, 40 (16.0\%) respondents study accountancy, 14 (5.6\%) study civil engineering, $50(20.0 \%)$ study electrical/electronic engineering, $2(0.8 \%)$ study environmental studies, 128 (51.2.0\%) study hospitality \& leisure management, $5(2.0 \%)$ study mechanical engineering, $8(3.2 \%)$ study quantity survey while 2 
(0.8\%) study statistics.

Table 4: Distribution by Course of Study

\begin{tabular}{|c|c|c|c|c|c|}
\hline & & Frequency & Percent & Valid Percent & Cumulative Percent \\
\hline \multirow{5}{*}{ Valid } & Accountancy & 42 & 16.8 & 16.8 & 16.8 \\
\hline & Electrical/Electronics & 50 & 20.0 & 20.0 & 36.8 \\
\hline & Mechanical Engineering & 5 & 2.0 & 2.0 & 38.8 \\
\hline & Others & 153 & 61.2 & 61.2 & 100.0 \\
\hline & Total & 250 & 100.0 & 100.0 & \\
\hline
\end{tabular}

Table 4 and Figure 4 shows that 42 (16.8\%) respondents study accountancy, 50 (20.0\%) study electrical/electronic engineering, $5(2.0 \%)$ study mechanical engineering while $153(61.2 \%)$ study other courses.

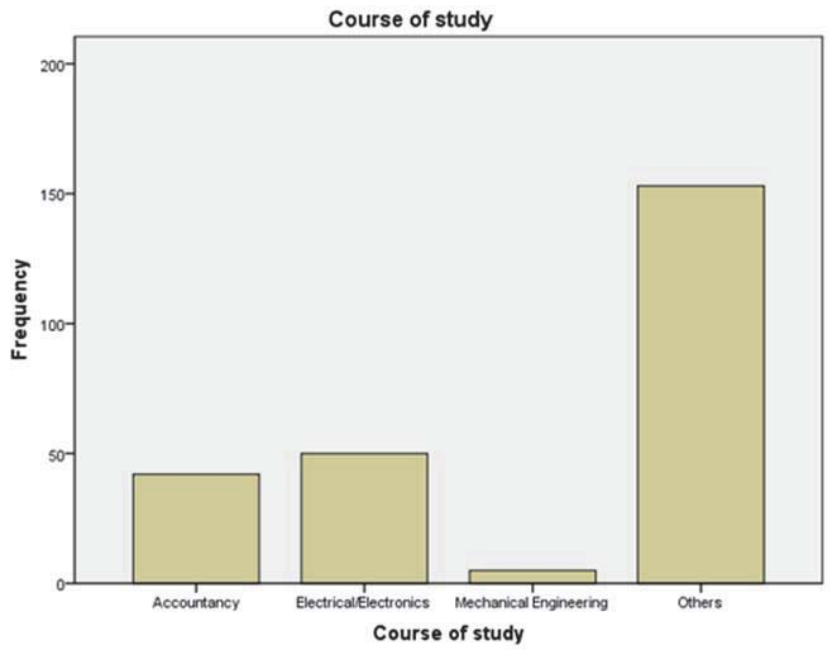

Figure 4: Distribution by Course of Study

2.2.2 Research question 2: Are there relevant teaching/training facilities with which entrepreneurial skills could be acquired by polytechnic students?

Table 5: Distribution by Availability of Relevant Teaching/Skill Training Facilities

\section{Variable}

Relevant training equipment are available for my course of study The available training equipment are not enough to cope with the number of students

I always have access to using the equipment during practical training

The available equipment are not in good state

There is always power supply to power the machines during practical training

The available equipment are obsolete

There are experts (technologists) to set and use the equipment to train me during practical training

Though equipment are there but I was never trained with it

There are adequate training/working equipment where I did my

IT/SIWES

I had opportunity of using equipment which I did not have access to in my school during my IT/SIWES

$\begin{array}{cccc}\text { Agree } & \begin{array}{c}\text { Strongly } \\ \text { Agree }\end{array} & \text { Disagree } & \begin{array}{c}\text { Strongly } \\ \text { Disagree } \\ 165(66.0 \%)\end{array} \\ 69(27.6 \%) & 5(2.0 \%) & 11(4.4 \%) & 13(8.4 \%) \\ 46(18.4 \%) & 53(21.2 \%) & 130(52.0 \%) & 21 \\ 45(18.0 \%) & 17(6.8 \%) & 28(11.2 \%) & 160(64.09 \%) \\ 125(50.0 \%) & 55(22.0 \%) & 69(27.6 \%) & 1(0.4) \\ 156(62.4 \%) & 46(18.4 \%) & 20(8.0 \%) & 28(11.2 \%) \\ 114(45.6 \%) & 55(22.0 \%) & 81(32.4 \%) & - \\ 16(6.4 \%) & 48(19.2 \%) & 172(68.8 \%) & 14(5.6 \%) \\ 157(62.8 \%) & 6(2.4 \%) & 85(34.0 \%) & 2(0.8 \%) \\ 42(16.0 \%) & 47(18.8 \%) & 33(13.2 \%) & 128(51.2 \%) \\ 43(17.2 \%) & 176(70.4 \%) & 7(2.8 \%) & 24(9.6 \%)\end{array}$


Table 5 shows that $69(27.6 \%)$ respondents agreed that relevant training equipment are available for their course of study, 5 (2.0\%) strongly agreed, 11 (4.4\%) disagreed and 165 (66.0\%) strongly disagreed. Also, 46 (18.4\%) respondents agreed that the available training equipment are not enough to cope with the number of students, $53(21.2 \%)$ agreed strongly, 130 (52.0\%) disagreed and 21 (8.4\%) disagreed strongly. Forty-five (18.0\%) respondents agreed that they always have access to using the equipment during practical training, 17 (6.8\%) agreed strongly, 28 (11.2\%) disagreed while $160(64.0 \%)$ disagreed strongly. Likewise, 125 (50.0\%) respondents agreed that available equipment are not in good state, 55 (22.0\%) agreed strongly, 69 (27.6\%) disagreed and $1(0.4 \%)$ disagreed strongly. One hundred and fifty-six $(62.4 \%)$ respondents agreed there is always power supply to power the machines during practical training, 46 (18.4\%) agreed strongly, 20 (8.0\%) disagreed and 28 (11.2\%) disagreed strongly; while $114(45.6 \%)$ respondents agreed that the available equipment are obsolete, 55 (22.0\%) agreed strongly and 81 (32.4\%) disagreed. sixteen (6.4\%) agreed that there are experts (technologists) to set and use the equipment to train them during practical training, $48(19.2 \%)$ agreed strongly, 172 (68.8\%) disagreed and 14 (5.6\%) disagreed strongly; $157(62.8 \%)$ respondents agreed that they were never trained with equipment though available, 6 (2.4\%) agreed strongly, 85 (34.0\%) disagreed and $2(0.8 \%)$ disagreed strongly. Forty-two (16.8\%) respondents agreed that there are adequate training/working equipment where they did their IT/SIWES, 47 (18.8\%) agreed strongly, 33 (13.2\%) disagreed and 128 (51.2\%) disagreed strongly; 43 (17.2\%) respondents agreed that they had the opportunity of working with relevant equipment which they did not have access to in their school during IT/SIWES, 176 (70.4\%) agreed strongly, 7 (2.8\%) disagreed and 24 disagreed strongly.

\subsubsection{Research question 3: Do polytechnic students do their Industrial Training (I.T)/Students Industrial Work} Experience Scheme (SIWES) programs in job areas related to their courses of studies?

Table 6: Distribution by Going on IT/SIWES

\begin{tabular}{|c|c|c|c|c|}
\hline Variable & Agree & $\begin{array}{l}\text { Strongly } \\
\text { Agree }\end{array}$ & Disagree & $\begin{array}{l}\text { Strongly } \\
\text { Disagree }\end{array}$ \\
\hline Going on IT/SIWES after my OND was essentially compulsory & $135(54.0 \%)$ & $85(34.0 \%)$ & $5(2.0 \%)$ & $25(10.0 \%)$ \\
\hline $\begin{array}{l}\text { I may not go on IT/ SIWES provided I get someone to give me } \\
\text { certificate of attendance even without attending }\end{array}$ & $144(57.6 \%)$ & $19(7.6 \%)$ & $58(23.2 \%)$ & $29(11.6 \%)$ \\
\hline $\begin{array}{l}\text { It does not matter whether or not I do my IT/SIWES in job areas } \\
\text { related to my course of study, what is important is just to do it } \\
\text { anywhere }\end{array}$ & $137(54.4 \%)$ & $56(22.4 \%)$ & $15(6.0)$ & $42(16.8 \%)$ \\
\hline I did my IT/SIWES in job area related to my course of study & $186(74.4 \%)$ & $32(12.8 \%)$ & $20(8.0 \%)$ & $12(4.8 \%)$ \\
\hline $\begin{array}{l}\text { I could not get a place in my course of study to do my IT/SIWES } \\
\text { but I did it in some other place }\end{array}$ & $13(5.2 \%)$ & $50(20.0 \%)$ & $153(61.3 \%)$ & $34(13.6 \%)$ \\
\hline $\begin{array}{l}\text { I prefer to do my IT/SIWES where I would be paid than a place } \\
\text { related to my course of study without payment }\end{array}$ & $149(59.6 \%)$ & $26(10.4 \%)$ & $47(18.8 \%)$ & $28(11.2 \%)$ \\
\hline $\begin{array}{l}\text { My primary assignment where I did my IT/SIWES was directly } \\
\text { related to my course of study }\end{array}$ & $165(66.0 \%)$ & $56(22.4 \%)$ & $4(1.6 \%)$ & $25(10.0 \%)$ \\
\hline I acquired relevant skills during my IT/SIWES program & $44(17.6 \%)$ & $169(67.6 \%)$ & $32(12.8 \%)$ & $5(2.0 \%)$ \\
\hline $\begin{array}{l}\text { I sought someone who signed my logbook and issued me } \\
\text { certificate of attendance of IT/SIWES because I could not get a } \\
\text { place to do it }\end{array}$ & $3(1.2 \%)$ & 35 (14.0\%) & $170(68.0 \%)$ & $42(1$ \\
\hline
\end{tabular}

From Table 6, 135 (54.0\%) respondents agreed that going on IT/SIWES after their OND was essentially compulsory, 85 (34.0\%) agreed strongly, 5 (2.0\%) disagreed and 25 (10.0\%) disagreed strongly. One hundred and forty-four (57.6\%) respondents agreed that they may not go on IT/SIWES provided someone could give them certificates of attendance without attending, 19 (7.6\%) agreed strongly, 58 (23.2\%) disagreed and 29 (11.6\%) disagreed strongly; 137 (54.8\%) agreed that it does not matter whether or not they do their IT/SIWES in job areas related to my course of study, what is important is just to do it anywhere, 56 (22.4\%) agreed strongly, 15 (6.0\%) disagreed while 42 (16.8\%) disagreed strongly. Also, $186(74.4 \%)$ respondents agreed that they did their IT/SIWES in job areas related to their courses of study, 32 (12.8\%) agreed strongly, 20 (8.0\%) disagreed and 12 (4.8\%) disagreed strongly. Thirteen (5.2\%) respondents agreed that they could not get a place to do their IT/SIWES in places related to their course of study, $50(20.0 \%)$ agreed strongly, $153(61.2 \%)$ disagreed while $34(13.6 \%)$ disagreed strongly; 149 (59.6\%) respondents agreed that they prefer to do their IT/SIWES where they would be paid than a place related to their course of study without payment, $26(10.4 \%)$ agreed strongly, 47 (18.8\%) disagreed and 28 disagreed strongly. 
In the same vein, $165(66.0 \%)$ respondents agreed that their primary assignment on IT/SIWES was directly related to my course of study, 56 (22.4\%) agreed strongly, 4 (1.6\%) disagreed and 25 (10.0\%) disagreed strongly; while 44 (17.6\%) respondents agreed that they acquired relevant skills during IT/SIWES program, 169 (67.6\%) agreed strongly, $32(12.8 \%)$ disagreed and 5 (2.0\%) disagreed strongly; and, 3 (1.2\%) agreed that they sought someone who signed their logbook and issued to them certificates of attendance of IT/SIWES because they could not get a place to do it, 35 (14.0\%) agreed strongly, 170 (68.0\%) disagreed and 42 (16.8\%) disagreed strongly.

\subsubsection{Research question 4: What are the attitudes of students of polytechnics towards acquisition of entrepreneurial skills?}

Table 7: Distribution by Students' Attitudes towards Acquisition of Entrepreneurial Skills

\section{Variable}

I may not go on IT/ SIWES provided I get someone to give me certificate of attendance even without attending

It does not matter whether or not I do my IT/SIWES in job areas related to my course of study, what is important is just to do it anywhere I prefer to do my IT/SIWES where I would be paid than a place related to my course of study without payment

$\begin{array}{cccc}\text { Agree } & \begin{array}{c}\text { Strongly } \\ \text { Agree }\end{array} & \text { Disagree } & \begin{array}{c}\text { Strongly } \\ \text { Disagree }\end{array} \\ 144(57.6 \%) & 19(7.6 \%) & 58(23.2 \%) & 29(11.6 \%) \\ 137(54.4 \%) & 56(22.4 \%) & 15(6.0) & 42(16.8 \%) \\ 149(59.6 \%) & 26(10.4 \%) & 47(18.8 \%) & 28(11.2 \%)\end{array}$

Analysis on Table 7 reveals that 144 (57.6\%) and 19 (7.6\%) agree and strongly agree respectively to not going on IT/SIWES provided there is some to issue certificates of attendance to the students. On the other hand, $58(23.2 \%)$ and $29(11.6 \%)$ disagree and strongly disagree respectively. Also, $137(54.4 \%)$ and $56(22.4 \%)$ felt that they could just do their IT/SIWES anywhere whether or not it related to their courses of study. Disappointingly, 149 (59.6\%) and 26 (10.4\%) respectively agree and strongly agree to do their IT/SIWES where they would be paid though it might not relate to their courses of study rather than doing it where it relates to their courses of study but without payment. This is negative attitude and portends danger for employment prospects of polytechnic graduates having this kind attitude.

\section{Tests of Hypotheses}

\subsection{Hypothesis One}

The hypothesis states that "there is no significant relationship between the students' course of study and availability of teaching/training facilities with which entrepreneurial skills could be acquired by polytechnic students".

Course of study * Relevant training equipment are available for my course study Cross-tabulation Count

\begin{tabular}{|c|c|c|c|c|c|c|}
\hline & \multicolumn{3}{l|}{ Relevant training equipment are available for my course } & \multirow{2}{*}{ Total } \\
\cline { 2 - 5 } & & A & SA & D & SD & \\
\hline \multirow{3}{*}{ Course of study } & Accountancy & 42 & 0 & 0 & 0 & 42 \\
& Electrical/Electronics & 7 & 2 & 4 & 37 & 50 \\
& Mechanical Engineering & 1 & 2 & 2 & 0 & 5 \\
& Others & 19 & 1 & 5 & 128 & 153 \\
& & 69 & 5 & 11 & 165 & 250 \\
\hline
\end{tabular}

\section{Chi-Square Tests}

\begin{tabular}{|l|c|c|c|}
\hline & Value & df & Asymp. Sig. (2-sided) \\
\hline Pearson Chi-Square & $16.228^{\mathrm{a}}$ & 9 & .000 \\
Likelihood Ratio & 18.965 & 9 & .000 \\
Linear-by-Linear Association & 8.331 & 1 & .000 \\
N of Valid Cases & 250 & & \\
\hline
\end{tabular}

X2 table $=16.919, x 2$ calculated $=16.228, d f=9, p=0.05$. 
Since table value (16.919) is greater than calculated value (16.228) at 0.05 level of significance, the hypothesis is accepted.

\subsection{Hypothesis Two}

The hypothesis states "there is no significant difference between the sex of students of polytechnics and their attitudes towards acquisition of entrepreneurial skills"

Sex * I prefer to do my IT/SIWES where I would be paid than a place related to my course of study without payment Cross-tabulation Count

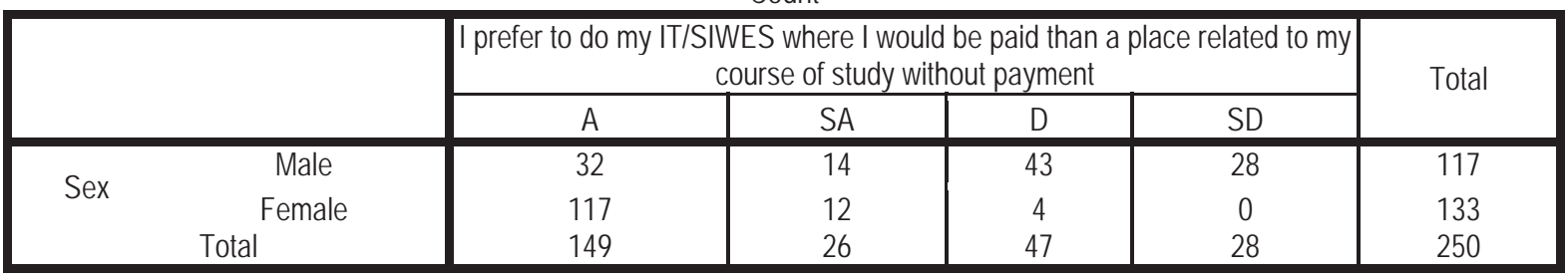

\begin{tabular}{|l|c|c|c|}
\hline \multicolumn{3}{|c|}{ Chi-Square Tests } \\
\cline { 2 - 4 } & Value & df & Asymp. Sig. (2-sided) \\
\hline Pearson Chi-Square & $10.843^{\mathrm{a}}$ & 3 & .000 \\
Likelihood Ratio & 12.728 & 3 & .000 \\
Linear-by-Linear Association & 10.467 & 1 & .000 \\
N of Valid Cases & 250 & & \\
\hline
\end{tabular}

X2 table $=7.815, \mathrm{X}$ calculated $=10.843, \mathrm{df}=3, \mathrm{p}=0.05$.

Since calculated value at 0.05 level of significance is less than table value $(7.815<10.843)$, the hypothesis is rejected and restated as "there will be significant difference between the sex of students and of polytechnics and their attitude towards acquisition of entrepreneurial skills"

\subsection{Hypothesis Three}

The hypothesis states that "there will be no significant difference between the year of program of student and whether they do their IT/SIWES in job areas related to their course of studies".

Year of program * I did my IT/SIWES in job area related to my course of study Cross-tabulation

Count

\begin{tabular}{|cc|c|c|c|c|c|}
\hline & & \multicolumn{3}{l|}{ I did my IT/SIWES in job area related to my course of study } & \multirow{2}{*}{ Total } \\
\cline { 3 - 7 } & & A & SA & D & SD & \\
\hline \multirow{3}{*}{ Year of program } & HND 1 & 97 & 6 & 5 & 0 & 108 \\
& HND 2 & 89 & 26 & 15 & 12 & 142 \\
Total & & 186 & 32 & 20 & 12 & 250 \\
\hline
\end{tabular}

\section{Chi-Square Tests}

\begin{tabular}{|l|c|c|c|}
\hline & Value & df & Asymp. Sig. (2-sided) \\
\hline Pearson Chi-Square & $2.570^{\mathrm{a}}$ & 3 & .000 \\
Likelihood Ratio & 3.105 & 3 & .000 \\
Linear-by-Linear Association & 2.201 & 1 & .000 \\
N of Valid Cases & 250 & & \\
\hline
\end{tabular}

$\mathrm{x} 2$ table $=2.570, \mathrm{x}^{2}$ calculated $=7.815, \mathrm{df}=3, \mathrm{p}=0.05$.

Since the calculated value (2.570) at 0.05 level of significance is less than the table (7.815), the hypothesis is accepted. 


\section{Findings}

The results showed that there are well over 50 different courses from which polytechnic students could acquire entrepreneurial skills. It, therefore, becomes the responsibilities of both the lecturers and the students to explore entrepreneurial skills in these courses with a view to imparting the polytechnic students. The analysis of the data in Table 3 indicated Hospitality and Leisure, Electrical and Electronics, and accountancy have the highest number of 120 (48\%), $50(20 \%)$ and $40(16 \%)$ of students respectively. Availability of relevant teaching/skill training facilities was lacking. From the analysis of the data on Table 5, about $176(70 \%)$ disagree and strongly disagree having relevant training equipment for various courses of study being undertaking in polytechnics. Also about 188 (76\%) disagree and strongly disagree always having access to using equipment for skills acquisition while in school. About 169 (67\%) agree and strongly agree that the available skills acquisition equipment are obsolete. Also, 186 (75\%) said that there were no technologist to guide them through using the available training equipment during their practical training, while about 164 (65\%) said that they were never trained with any of the available equipment. All these are not good enough as it only makes the form of education acquired by polytechnic students not to differ from liberal education devoid of entrepreneurial vocational skills.

Both IT and SIWES positively contributed to entrepreneurial skills acquisition by polytechnic students. About 220 (88\%) considered going for IT/SIWES essentially compulsory. Also, about 215 (86\%) said that they did their IT/SIWES in job areas related to their courses of study. Majority, 203 (85\%) confessed acquiring relevant entrepreneurial skills during IT/SIWES. Nevertheless, the attitudes of the polytechnic students towards entrepreneurial skills acquisition could be seen as negative and not encouraging as evidenced from the analysis on Table 7. For instance, about 163 (65\%) considered IT/SIWES unnecessary if they could get someone to give to them certificate of attendance even without attending. Also, about 193 (76\%) believed that they could just do their IT/SIWES anywhere regardless of whether or not it related to their courses of study. Their attitudes also revealed prioritizing receiving wages over and above acquisition of entrepreneurial skills as about $175(70 \%)$ agree and strongly agree to do their IT/SIWES where they would be paid than a place though related to their courses of study without payment. This attitude is bad and calls for urgent attitudinal reorientation for polytechnic students.

\section{Conclusions}

From the results of this research, the following conclusions could be drawn:

1. There are sufficient and enough courses of study from which polytechnic students could acquire entrepreneurial skills if adequately explored.

2. Adequate availability of relevant equipment that could be used for practical training in entrepreneurial skills acquisition was lacking as well as technical personnel to guide polytechnic students through using the available training equipment.

3. IT/SIWES has positively impacted on entrepreneurial skills acquisition among polytechnic students and should be kept up.

4. Polytechnic students have poor and negative attitudes towards acquisition of entrepreneurial skills.

\section{Recommendations}

Consequent upon the forgoing, the following suggestions are made in respect of subject of this research:

1. Acquirable entrepreneurial skills should be imbedded in all courses of study being offered in polytechnics.

2. Training without relevant equipment will only lead to frustration. All stakeholders in polytechnic education should spare no efforts in ensuring availability of entrepreneurial and vocational skills acquisition facilities in polytechnics.

3. More incentives should be provided for both the students and proprietors/proprietresses of workplaces where prospective polytechnic students could do their IT/SIWES.

4. Drastic and conscious change and attitudinal reorientation of polytechnic students towards IT/SIWES is urgently needed. Prospective IT/SIWES candidates should be given thorough supervision during their IT/SIWES program to ensure total compliance to modus operandi. 


\section{References}

Abubakar, M.S. (2010). Revitalizing TVET for technology entrepreneurship and industrial development: measure, design and applicability. A paper presented at the national centre for technology management. June, 6th-18 and Namkere, J. U. (2013). Entrepreneurial Skills in Technical Vocational Education and Training as A Strategic Approach for Achieving Youth Empowerment in Nigeria. International Journal of Humanities and Social Science. 3(5), 303-310.

Adeyemo, S. A. (2009). Understanding and Acquisition of Entrepreneurial Skills: A pedagogical Re-orientation for Classroom Teacher in Science Education. Journal of Turkish Science Education. 6 (3), 57-65.

Araba, S. (2013). Entrepreneurial Education as a Tool for Reducing Unemployment in Comfort, O. C. and Bonaventure, O. C. (2012). Students' Entrepreneurial Skill Acquisition through Students Industrial Work Experience Scheme (SIWES) in Nigeria: An Analytical Approach. International Journal of Independent Research and Studies. 1(3), 97-105.

Dhenak, M. S. (2010). 15 Factors Affecting Entrepreneurial Growth. Retrieved September 12, 2013 from www.scribd.com/doc/.../15Factors-Affecting-Entrepreneurial-Growth

Gamberi, J (2009). The Importance of Skills Acquisition: A Challenge to Nigerian Legislators. Retrieved September 20, 2013 from www.nasslegislatonline.com

Joint Admissions and Matriculation Board (JAMB), (2011). Unified Tertiary Matriculation Examination Brochure, JAMB Abuja, Nigeria. 459-513.

Kitzer, L.E. (2007) "Entrepreneur development": new venture creation. In Maigida, J. F., Saba, T. M. and Namkere, J. U. (2013). Entrepreneurial Skills in Technical Vocational Education and Training as A Strategic Approach for Achieving Youth Empowerment in Nigeria. International Journal of Humanities and Social Science. 3(5), 303-310.

Klaipeda Business School (2009). Erasmus Intensive Programme Project "Improvement of Entrepreneurial Skills in a Multicultural Environment" Retrieved August 16, 2013 from www.kvam.It/erasmus-ip-projec

Maigida, J. F., Saba, T. M. and Namkere, J. U. (2013). Entrepreneurial Skills in Technical Vocational Education and Training as A Strategic Approach for Achieving Youth Empowerment in Nigeria. International Journal of Humanities and Social Science. 3(5), 303-310.

Nwanaka, C. R. and Amaechule, S. (2011). Skills Acquisition: Imperative for Business Studies Educators among Secondary Schools in Rivers State. Mediterranean Journal of Social Sciences, 2(7) 37-43 Retrieved September 25, 2013 from www.mcser.org limages/stories/MJSS-Special-issues/.../nwanaka-c-r.pdf

Osemeke, M. (2012). Entrepreneurial Development and Interventionist Agencies in Nigeria. International Journal of Business and Social Science, Special Issue. 3(8), 255-265.

Oziengbe, U.V. (2009).Industrializing the Nigerian Society through creative skill Acquisition Vocational and Technical Education Programme. International NGO Journal.4 (4).142-145. 